\title{
Chemical composition and livestock ingestion of carob (Ceratonia siliqua L.) seeds
}

\author{
MOH'D KHAIR J. EL-SHATNAWI AND KHALIL I. EREIFEJ
}

Authors are associate professor, Department of Natural Resources and the Environment, Faculty of Agriculture, Jordan University of Science and Technology, PO Box 3030, Irbid, Jordan, E-mail: mkhair@just.edu.jo, and professor, Department of Nutrition and Food Technology, Faculty of Agriculture, Jordan University of Science and Technology, PO Box 3030, Irbid, Jordan, E-mail: ereifej@just.edu.jo.

\begin{abstract}
Pods and seeds from carob Ceratonia siliqua $\mathbf{L}$. trees growing in Ajloun Mountainous forests and rangelands in Jordan were analyzed for their proximate analysis, $\mathrm{Ca}$ and $\mathrm{P}$ contents, and also the effects of ingestion of seeds by sheep and goat on the germination were investigated. Carob seed has hard seed coat dormancy, and seed scarification increased germination from $10.2 \%$ in non-scarified to $85.4 \%$ after scarification. Germination percentages for seeds that were ingested by sheep were $73.5,61.8$, 39.3 , and $0.0 \%$ for ingestion periods of $24,48,72$, and 96 hours, respectively; whereas, it was $56.8,79.9,50.1,13.7$, and $1.1 \%$ for seeds dispersed from goat after 24, 48, 72, 96, and 120 hours. Carob seeds contained higher amounts of protein, fiber, fat and Ca than deseeded pods. However, the latter contained more carbohydrates and $\mathbf{P}$ than seeds. Carob pods and seeds contained sufficient crude protein and energy to meet the maintenance and lactation requirements of ewes, but $\mathrm{Ca}$ and $\mathrm{P}$ contents were not adequate by themselves.
\end{abstract}

Key Words: Germination, fiber, forest, goat, Jordan, protein, sheep

Carob pods are produced by the evergreen sclerophyllous tree Ceratonia siliqua L., a species that is native to western Asia and northern Africa. Various chemical and physiological aspects of carob plants have been investigated in many countries around the world (Coit 1967, Orphanos and Papaconstantinou 1969, Calixto and Canellas 1982, Wursch 1987, Gaitis et al. 1994, Marakis 1996). Although carob trees are found in great abundance in Jordanian forests and rangelands, thorough investigations on its use as feed source in sheep industry are very rare.

Animals acting as seed dispersal agents are instrumental in maintaining and spreading woody plant populations (Janzen 1983), and ungulates often play an important role in this context. Ruminants, including sheep and goat, consume considerable amounts of carob fruits. Carob provides nutritious pods and extremely hard, smooth seeds that may evade or resist strong molars. Seeds of many forest trees regularly pass through the digestive tracts of animals unharmed. However, the digestive juices of many animals may weaken the seed coat and favor

We thank Dr. Hani Z. Ghosheh for his critical comments, helpful suggestions and editorial inputs.

Manuscript accepted 16 Dec. 00.

\section{Resumen}

Vainas y semillas de "Carob" (Ceratonia siliqua L.) colectadas de árboles de los bosques montañosos y pastizales de Ajloun se sometieron al análisis proximal y se les determinó su contenido de Ca y P. Además, en este estudio se investigaron los efectos de la ingestión de la semilla por ovinos y caprinos en la geminación. La semilla de "Carob" manifiesta una dormancia por la presencia de una capa dura, y la escarificación de la semilla incrementó la geminación de $10.2 \%$ a $85.4 \%$. Los porcentajes de germinación de la semilla ingerida por ovinos fueron de $73.5,61.8$, 39.3, and $0.0 \%$ para los períodos de ingestión de $24,48,72$ and 96 horas, respectivamente, mientras que los porcentajes fueron de 56.8, 79.9, 50.1, 13.7 y 1.1\% para las semilla dispersadas por los caprinos después de 24, 48, 72, 96 y 120 horas. Las semillas de "Carob" mostraron mayores cantidades de proteína, fibra, grasa y calcio que las vainas sin semilla. Sin embargo, estas últimas presentaron más carbohidratos y $\mathbf{P}$ que las semillas. Las semillas y vainas de "Carob" contenían suficiente proteína cruda y energía para satisfacer los requerimientos de mantenimiento y lactancia de las borregas, pero los contenidos de Ca y $\mathbf{P}$ no fueron adecuados.

water absorption and eventually, germination (Barnes et al. 1998). Seeds may be destroyed by mastication and digestion (Thill et al. 1986) or dispersed to new sites. In this context several investigators have studied carob trees, pods (beans) and their seeds (Marakis 1980, Brito de Carvalho 1987, Marakis et al. 1993).

Carob trees dominate the vegetation of many sites of the mountainous Ajloun forests. Unfortunately, the nutritive value of carob seeds and pods, and the effects of livestock on the viability of the seeds were not investigated in Jordan. Therefore, the objective was to study the chemical compostion of the carob seeds and pods, and to investigate the effect of carob seeds ingestion by sheep and goat.

\section{Materials and Methods}

\section{Site Description}

The carob trees which are the focus of this study are located on the Ajloun mountains in northern Jordan, situated $35 \mathrm{~km}$ south of Irbid $\left(32^{\circ} 21^{\prime} \mathrm{N}, 35^{\circ} 49^{\prime} \mathrm{E}\right)$. Altitude is $920 \mathrm{~m}$ and the site is characterized by having 30 to $70 \%$ slope. The soil is a weakly cracked and deep silty clay. Natural vegetation is typical of 
Mediterranean forests dominated by oak (Quercus spp.) and/or carob (Ceratonia siliqua) trees (Anon 1998). Mean annual precipitation for that site is $500 \mathrm{~mm}$ occurs during October to April. Highest accumulations and the most rapid plant growth occurred during the period from January to March and ceases during May (Anon 1997).

\section{Chemical analysis}

In 1995 and 1996, mature carob pods were collected from 72 trees. Crude protein ( $\mathrm{N} X$ 6.25), fat, fiber, and ash contents, were determined in pods and seeds according to AOAC (1984) procedures. Carbohydrates were calculated by difference as follows: \% Carbohydrate $=100$ $(\%$ Protein $+\%$ Fat $+\%$ Fiber $+\%$ Ash $)$. Calcium $(\mathrm{Ca})$ contents of pods and seeds were determined with an atomic absorption spectrophotometer (Unicam, model SP9, UK) using the wet digestion method with a mixture of nitric, sulfuric and perchloric acids (10:1:4). Phosphorus (P) content in pods and seeds was determined according to Watanabe and Olsen (1965). All chemical composition are reported on dry weight basis. No significant differences for all measured traits were detected between the 2 seasons and data from the 2 growing seasons were therefore combined and subjected to analysis of variance according to Steel and Torrie (1980).

\section{Germination of Dispersed Seeds}

Ten, 4-year old sheep ewes and goats were housed into 2 separate pens $\left(40 \mathrm{~m}^{2}\right)$ for the purpose of this experiment. These animals were fed on wheat straw and ground barley. The animals were not given any food for 24 hours before starting the experiment, so that the animals would consume large amounts of carob seeds. Carob pods were hand-chopped into 3-4 pieces, and were provided to animals for 4 hours. Sheep and goats were then transferred to 2 separate clean pens to avoid contamination from non-fed carob seeds. Manure was collected 24, 48, 72, 96, and 120 hours after dosing. At the end of each collecting period, seeds were separated and washed from the manure.

Germination tests were conducted on carob seeds that were either scarified by abrasive glass paper, non-scarified, or animal dispersed. For each treatment, ten petridishes $(15 \times 1.5 \mathrm{~cm})$ were used, each contained 10 carob seeds and were incubated at $20^{\circ} \mathrm{C}$ for 14 days. Treatments of scarified carob seeds, non-scarified, and the combination of live stock type (sheep or goat) and dispersal time $(24,48,72,96$, or 120 hours) were arranged in a randomized complete block design with ten replications. Germinated seeds were counted every 24 hours. Germination percentage means were separated and compared according to the least significant difference (LSD) test as described by Steel and Torrie (1980). Polynomial Regression Model for germination \% as dependent variables and ingestion period length at stomach of sheep or goat as independent variable was carried as described by Neter et al. (1989).

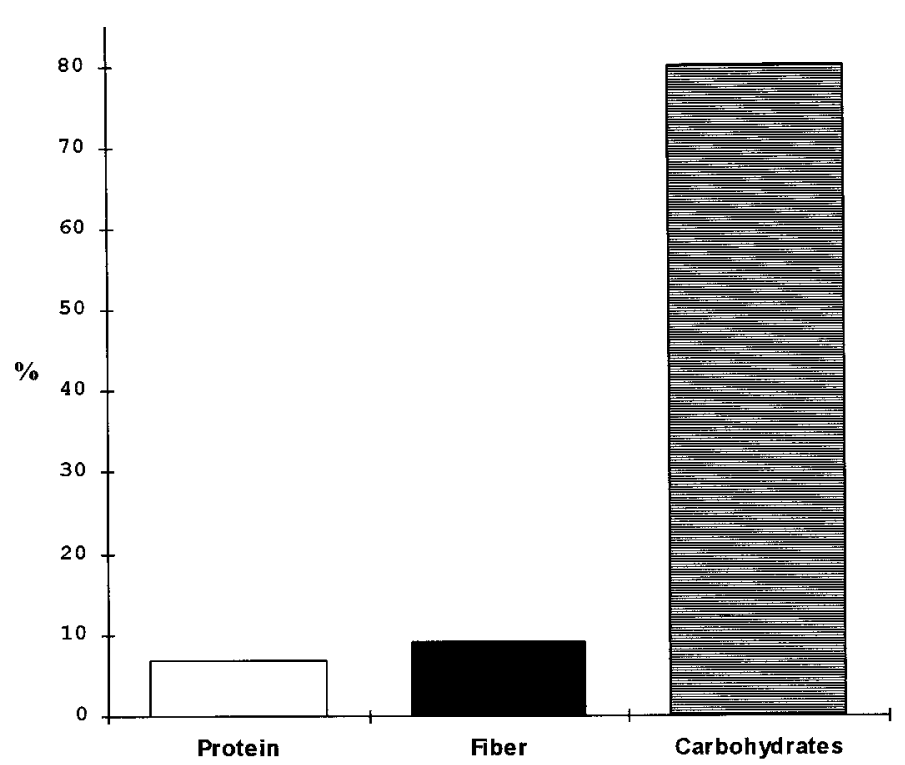

Fig. 1. Protein, fiber and carbohydrates composition of carob (Ceratonia siliqua L) pods collected from Ajloun forests rangeland.

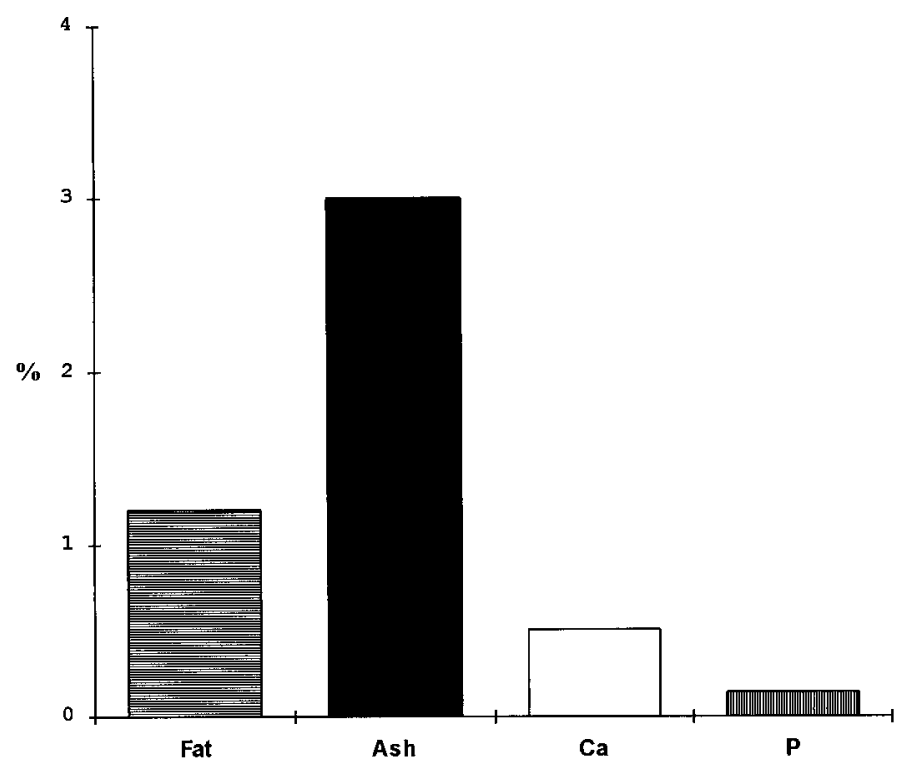

Fig. 2. Fat, ash, Ca and $P$ composition of carob (Ceratonia siliqua $L$ ) pods collected from Ajloun forests rangeland. 


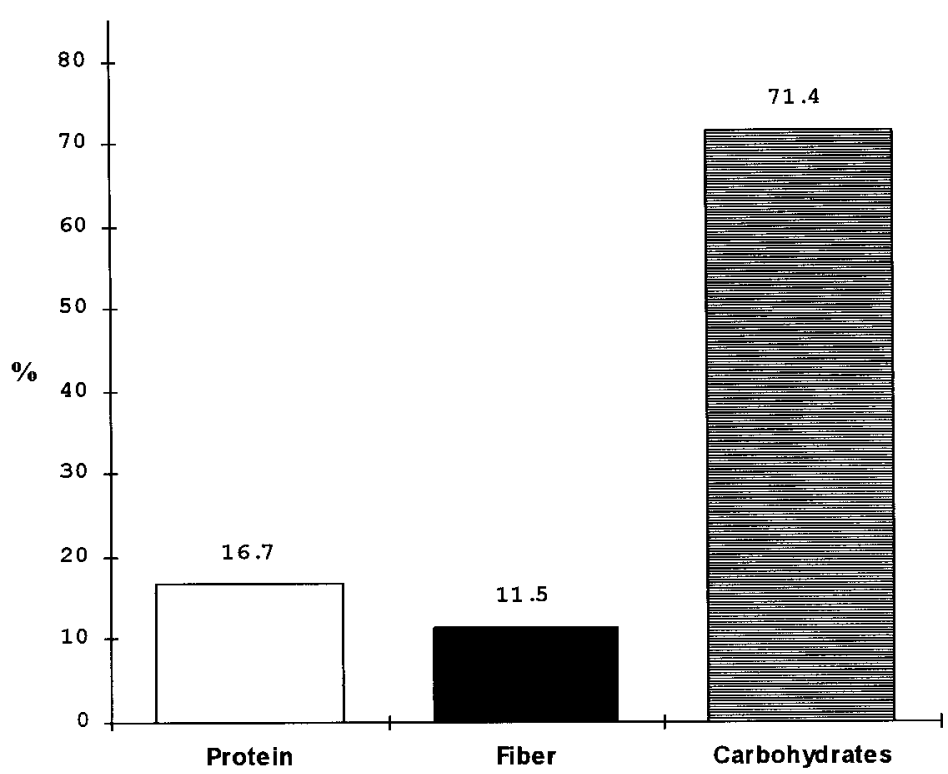

Fig. 3. Protein, fiber and carbohydrates composition of carob (Ceratonia siliqua $\mathrm{L}$ ) seeds collected from Ajloun forests rangeland.

1.2 and $2.9 \%$, respectively (Fig. 2 and 4 ). Considerable variations were observed in ash contents between pods and seeds (3.0 vs. $0.4 \%$ ash content) (Fig. 2 and 4 ). Calcium contents were $493(0.5 \%)$ and $674 \mathrm{mg} 100 \mathrm{~g}^{-1}(0.7 \%)$ in carob pods and seeds, whereas phosphorus content (Fig. 2 and 4) was $146 \mathrm{mg} 100 \mathrm{~g}^{-1}(0.15 \% \%)$ in carob pods, but $125 \mathrm{mg} 100 \mathrm{~g}^{-1}(0.13 \%)$ in seeds. Ca:P ratios were 5.1 and 6.4 in pods and seed, respectively (Fig. 5).

\section{Germination of Dispersed Seeds}

Germination of non-scarified seeds was $10.2 \%$, whereas the scarified germination was $85.4 \%$ (Fig. 6). Germination percentages for the seeds which were ingested by sheep and collected after 24, 48, 72 and 96 hours after ingestion were 73.5, 61.8, 39.3, and $0.0 \%$, respectively. Germination percentages were $56.8,79.9,50.1,13.7$, and $1.1 \%$ for seeds ingested by goats and dispersed after 24, 48, 72, 96, and 120 hours,

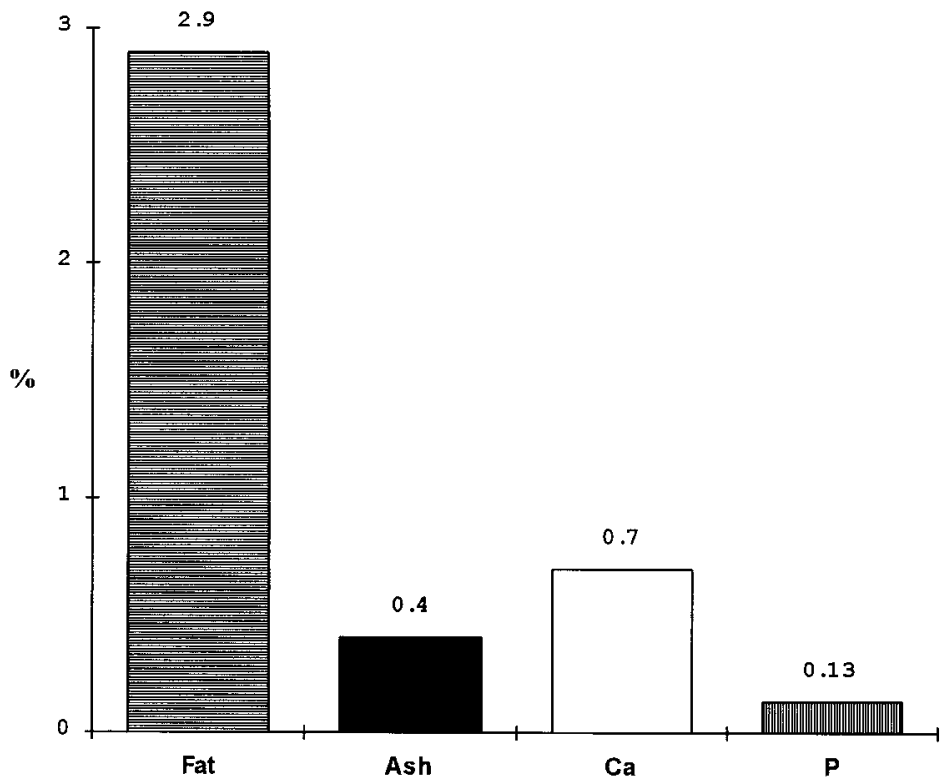

Fig. 4. Fat, ash, Ca and $P$ composition of carob (Ceratonia siliqua $L$ ) seeds collected from Ajloun forests rangeland.

respectively (Fig. 6). Seed dispersion from sheep terminated after 96 hours of ingestion, whereas goats continued to disperse seeds for a longer period than sheep. The linear, quadratic and cubic polynomial regression models for seed germination dispersed from goat were highly significant with $\mathrm{R}^{2}$ values of $0.86,0.87$, and 0.93 , respectively, and for those dispersed by sheep the $\mathrm{R}^{2}$ values were $0.72,0.72$, and 0.91 , respectively (Table 1 ).

\section{Discussion}

Jordan has a unimodal precipitation pattern, with a short rainy period followed by an extended dry period with limited opportunities for herbaceous forage production. Plant dormancy accelerates a decline in both quantity and quality of forage. Annual grasses may lose $75 \%$ of their protein content and up to $52 \%$ of their phosphorous during the dry season (Louis et al. 1983). Wheat and barley stubble grazing starts immediatly after harvesting in June and lasts until September, providing the basic diet for sheep throughout the summer into autumn when supplementary feeding starts (ACSAD 1983). The feeding value of the grass residue deteriorates after a month of harvesting and the animals begin losing weight. Supplementation with cotton seed meal or cereal grain at a rate of $100 \mathrm{~g} \mathrm{day}^{-1}$ could stop the weight losses (Turminini 1991). The amount of subsidized feed stuff is estimated around 444 thousand tons (FAO 1994). In autumn, sheep flocks depend on the remaining stubble and native pasture. Ceratonia siliqua L. is a native fodder tree found in many regions of the Middle East including Jordan. It is a valuable feed supplement during dry seasons and emergencies. Pods of Ceratonia siliqua have considerable feed potential in the semiarid and subhumid rangelands of Jordan.

Livestock usually require feed supplementation for 6 months in a normal year and 9 months during particularly dry years (Nesheiwat and Muhammed 1987). Protein contents of carob pods and seeds are high (16.7 and 6.8\%, respectively) and therefore represent a good source of protein for livestock during dry summers and autumns. Carbohydrates were $71 \%$ in the seeds and $80 \%$ in the pods, whereas fiber contents of pods $(9.2 \%)$ and seeds $(11.5 \%)$ were low indicating their importance as a highly quality source of fodder. Energy and protein are the most limiting nutrients to range livestock production (Holechek and Herbel 1986). El-Shatnawi and 


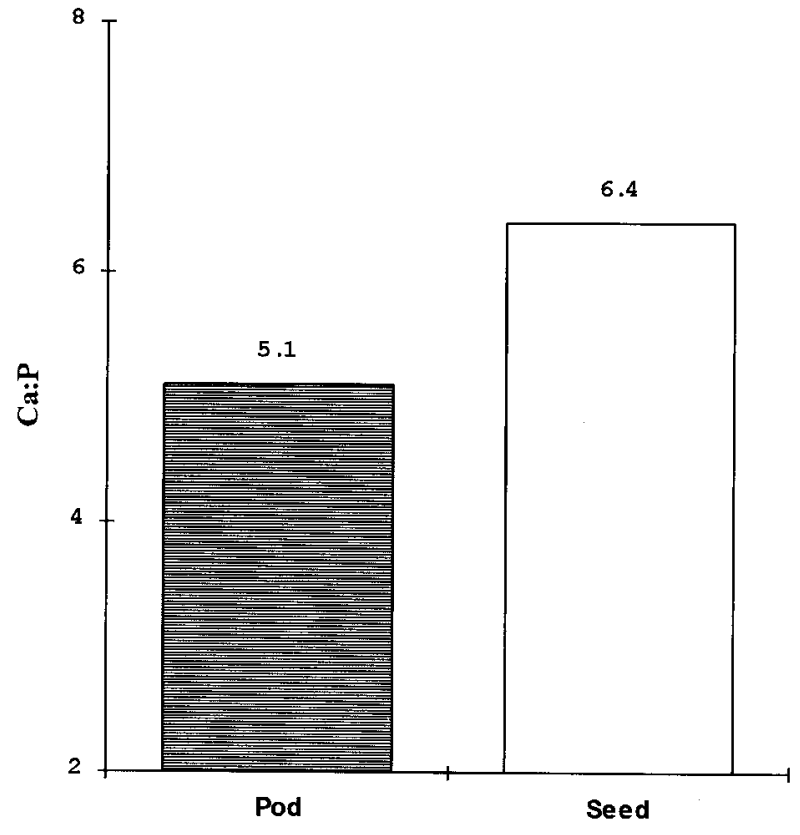

Fig. 5. Calicum:Phosphorous ratio in carob (Ceratonia siliqua $\mathrm{L}$ ) seeds and pods collected from Ajloun forests rangeland.

Mohawesh (2000) reported the importance of the woody plants as a feed supplement for livestock during summer and autumn seasons in the semiarid grasslands of Jordan. Our results showed that crude protein and carbohydrates contents in carob pods and seeds were sufficient to meet the maintenance and lactation requirements of ewes throughout the year. Ewes require 7 to $9 \%$ crude protein for maintenance and 10 to $12 \%$ for lactation. They also need $0.15 \%$ to $0.20 \% \mathrm{P}$ for maintenance and 0.25 to $0.30 \%$ for lactation (Holechek et al. 1998). Therefore, introducing carob fruits into livetock feeds will improve the nutritive value of their food and may minimize the need for grain supplement during summer and autumn.
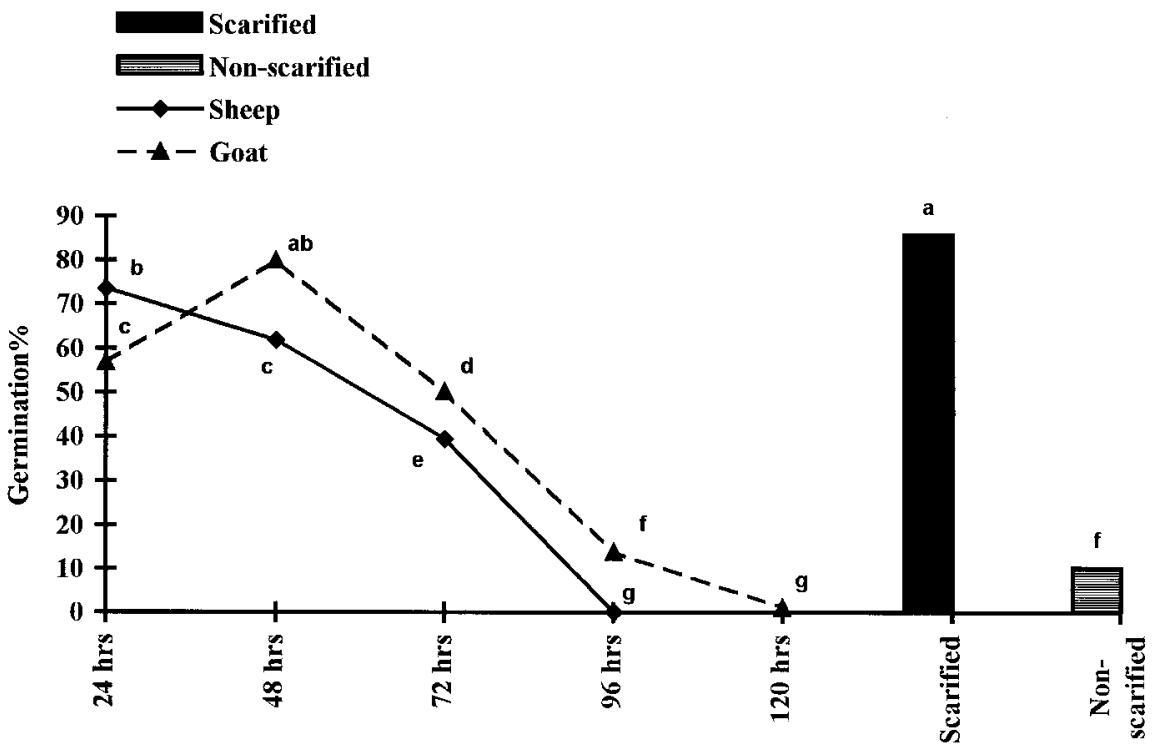

Seed treatment

Fig. 6. Germination \% of scarified, non-scarified and dispersed carob (Ceratonia siliqua L) seeds from Awasi sheep and Baladi goat after 24, 48, 72, 96, and 120 hours. Values with different letters differ significantly according to LSD at $\mathbf{P}<0.01$.
Carob seeds contain higher amounts of protein, fiber, fat and $\mathrm{Ca}$, than pods, whereas deseeded pods contained higher carbohydrates and $\mathrm{P}$ than seeds. Protein content was higher than previously reported in Greece (Marakis et al. 1987), Spain (Calixto and Canellas 1982), Portugal (Amaral-Collaco et al. 1987), Cyprus (Orphanos and Papaconstantinou 1969) and California (Coit 1967). The crude fat content was similar to those reported by Calixto and Canellas (1982) in Spanish carob. Fiber content of Jordanian carob was lower than the values reported by Amaral-Collaco et al. (1987) and Marakis (1996).

The results indicate that the hard seedcoat dormancy prevails in carob seeds. Hence, scarification increased germination from $10 \%$ to $85 \%$ (Fig. 6). The strongest relationships between seed germination and the length of incubation period in the digestive system of sheep and goat are cubic (Table 1). Maximum germination percentages were obtained when seeds were incubated for $24(74 \%)$ and 48 hours $(80 \%)$ in the digestive systems of sheep and goat, respectively. However, germination declined as the incubation period increased. Results agree with data reported by Fredrickson et al. (1997) who found longer seed incubation periods to reduce seed germination. Seed dispersal from sheep continued for only 4 days, whereas goat dispersed seeds for a longer period. The amount of dispersed seed decreased progressively with time for both livestock types. Germination of the seeds that were dispersed by goats after 48 hours was the highest. Seeds passing through the rumen quickly may not be scarified and therfore have a low germinability, but when scarified in the rumen for extended period may be detrimental to seed viability (Archer and Pyke 1991). Goats, as browsers, consume lower amounts of roughage compared with more concentrated feeds. Hofmann (1989) and Wallander et al. (1995) observed a negative relationship between roughage consumption and the amount of seed that passes with manure. This explains ability for less rumination and more viable seed passages in comparison with sheep. Carob provides nutritious pods that have smooth seeds with extremely hard coat which evade or resist strong molars. The seeds of many forest trees are adapted to passage through the digestive tracts of animals without being severely harmed. However, digestive juices may weaken the seed coat, and thus favor water absorption and eventually, germination (Barnes et al. 1998). 
Table 1. Coefficient of determinations (R2), $F$ values and regression coefficients for linear, quadratic, and cubic models for carob seeds germination \% dispersed from sheep and goat.

\begin{tabular}{lccccccc}
\hline \hline & \multicolumn{3}{c}{ Goat } & & \multicolumn{3}{c}{ Sheep } \\
\cline { 2 - 3 } \cline { 6 - 7 } & Linear & Quadratic & Cubic & & Linear & Quadratic & Cubic \\
\hline $\mathrm{R}^{2}$ & 0.864 & 0.874 & 0.9320 & & 0.718 & 0.7230 & 0.9140 \\
$\mathrm{~F}$ & 369.800 & 198.500 & 255.6000 & & 147.970 & 73.2600 & 197.6310 \\
$\mathrm{~b}_{0}$ & 81.291 & 91.245 & 42.6590 & & 87.267 & 91.9150 & -15.0190 \\
$\mathrm{~b}_{1}$ & -0.607 & -0.912 & 1.5930 & & -0.663 & -0.8050 & 4.7060 \\
$\mathrm{~b}_{2}$ & & 0.002 & -0.0320 & & 0.0008 & -0.0740 \\
$\mathrm{~b}_{3}$ & & 0.0001 & & & 0.003 \\
\hline
\end{tabular}

Carob fruits have a sweet taste; livestock may prefer them to other forest fruits. This would facilitate seed dispersal by sheep and goat. Results of this experiment confirm previous finding of Thill et al. (1986), that seeds consumed by animals are either destroyed by mastication and digestion or dispersed to new sites. Sheep and goat are very important dispersal agents for carob seeds and thus, instrumental in maintaining and spreading carob tree populations. Brown and Archer (1987) reported the effectiveness of livestock in dispersing hard-seeded legumes. Our results indicate mutalism relationships between carob trees and sheep and goat.

\section{Conclusion}

Carob trees provide shelter and nutritious fruit for livestock. Its pods and seeds are a good source for protein, carbohydrates, and fiber. Both pods and seeds contain enough crude protein and energy to meet the maintenance and lactation requirements of ewes. Livestock break the seed-coat dormancy and disperse seed to new sites. However, goats may be more efficient transporters of carob seeds because of their ability to disperse viable carob seeds over a longer period.

\section{Literature Cited}

ACSAD. 1983. Studies of Houd-Al Hamad. Animal production in the Jordanian Hamad ACSAD-Damascus (in Arabic).

Amaral-Collaco, M.T., J. I. Roseiro, G.A.. Avlino and H. Teixera. 1987. The quality of sugar content of two Portuguese carob varieties-Their influence on the technological transformation, p.11-18. In: P. Fito and A Mulet (eds), Proc. of $2^{\text {nd }}$ International Carob Symposium, Valencia, Spain (29 Sept-1Oct).

Anon. 1997. The Annual Report of Agricultural Statistics. Ministry of Agr., Amman, Jordan.
Anon. 1998. Jordan Country Study on Biological Diversity. The General Cooperation for the Environ.Protection. Amman, Jordan

AOAC. 1984. Official Methods of Analysis. Assoc. of Official Analytical Chemists. Washington, DC.

Archer, S. and D. Pyke. 1991. Plant-animal interactions affecting plant establishment and Range Manage. 44:558-565.

Barnes, B.V., D.R. Zak, S.R. Denton and S.H. Spurr. 1998. Forest Ecology. John Wiley \& Sons, Inc. New York.

Brito de Carvalho, J.H. 1987. Criteria for evaluation of carob varieties, p. 174-181. In: P. Fito and A. Mulet (eds), Proc. of $2^{\text {nd }}$ Internat. Carob Symp., Valencia, Spain (29 Sept-1Oct).

Brown, J. R. and S. Archer. 1987. Woody plant seed dispersal and gap formation in a North American subtropical savanna woodland: The role of domestic herbivores. Vegetatio 73:73--80.

Calixto, F.S. and J. Canellas. 1982. Components of nutritional interest in carob pods (Ceratonia siliqua L.). J. Food Sci. Agr. 33:1319-1323.

Coit, J.E. 1967. Carob varieties for the semiDigest 21:5-9.

Gaitis, F., S. Marakis and S. Diamantoglou. 1994. Carob varieties from Greek Island Lefkada. In: S. K. Manolis (ed.), Proc. of the $16^{\text {th }}$ Congress of Hellenic Soc. of Biol. Sci., Volos, Greece 5-7 May.

El-Shatnawi, M.J. and Y. Mohawesh. 2000. Seasonal chemical composition of saltbush in semiarid grasslands of Jordan. J. Range Manage. 53:211-214.

FAO. 1994. Sheep production under extensive systems in the Near East: Jordan pastoral system a case study. Near East Regional Office, Food and Agr. Organ. of the United Nations.

Fredrickson, E.L., R.E. Estell, K.E. Havestad, T. Kisksi, J.V. Toll, M.D. Remmenga. 1997. Effects of ruminant digestion on germination of lehmann lovegrass seed. J. Range Manage. 50:20-26.

Hofmann, R. R. 1989. Evolutionary steps of ecophysiological adaptation and diversification of ruminants: a comparative view of their digestive system. Oecologia 78:443-457. persistence on revegetated rangeland. J. arid southwest. Fruit Varieties and Hort.
Holechek, J.L., and C.H. Herbel. 1986. Supplementing range livestock. Rangelands 8:29-33.

Holechek, J.L., R.D. Pieper and C.H. Herbel. 1998. Range Management Principles and Practices. Prentice Hall, Englewood Cliffs, N.J.

Janzen, D. H. 1983. Dispersal of seeds by vertebrate guts In: D.J. Futuyma and M. Slatkin (eds.), Coevolution. Sinauer Association, Sunderland, Maine.

Louis, S.L., A. Dankintafo, B. Bookary, and N. Goumey. 1983. Seasonal influence on the nutritive value of the rangeland in Niger pastoral zone. Ministry of Rural Development US AID Tech. Bull. 2. Tahoua, Niger.

Marakis, S . 1980. New fungal strains for microbial protein production from carob beans. Unpublished Ph.D. Diss. University of Athens, Greece.

Marakis, S. 1996. Carob beans in food: Current status and future potentials-A critical appraisal. J. Food Sci. Tech. 33:365-383.

Marakis, S., J. Kalaitzakis, and K. Mitrakos. 1987. Criteria for recognizing carob tree varieties, p. 43-49. In: P. Fito and A. Mulet (eds), Proc. of $2^{\text {nd }}$ International Carob Symposium, Valencia, Spain (29 Sept-1Oct).

Marakis, S., M. Lambrakis, and S. Diamantoglou. 1993. Tannin chemistry of nine Cretan carob verities. Chimica Chronica, New Series 22:213-224.

Nesheiwat, K and J. Muhammed. 1987. Socio-economy and farming systems. Vol. 2 of the base-line study of Ma'in Pilot Project Perimeter. Amman-Jordan. MOA/FAO.

Neter J, W. Wasserman and M.H. Kutner. 1989. Applied Linear Regression Models. Richard D. IRWIN, INC. Boston, Mass., USA.

Orphanos, P. I. and J. Papaconstantinou. 1969. The Carob varieties of Cyprus.Cyprus Agr. Res. Inst. Tech. Bull. 5:1-13.

Steel, G. D. and J.H. Torrie. 1980. Principles and Procedures of Statistics: A Biometrical Approach. McGraw-Hill Inc. New York, N.Y

Thill, D. C., D.L. Zamora and D.L. Kambitsch. 1986. The germination and viability of excreted common crupina (Crupina vulgaris) achenes. Weed Sci. 34:237-241.

Turminini, A. 1991. By-products of crops and straw and formulation of rations. Range, feeds and animal production program. ICARDA, Aleppo.

Wallander, R. T., B.E. Olson and J.R. Lacey. 1995. Spotted knapweed seed viability after passing through sheep and mule deer. J. Range Manage. 48:145-149.

Watanabe, F.S. and S. Olsen. 1965. Test of an ascorbic acid method for determining phosphorus in water and $\mathrm{NaHCO}_{3}$ extracts from soil. Soil Sci. Soc. Amer. Proc. 21:677-678.

Wursch, P. 1987. Structure of tannins in carob pod and their antidiarrhoeic properties, $\mathrm{p}$. 93-97. In: P. Fito and A. Mulet (eds.), Proc. of $2^{\text {nd }}$ Internat. Carob Symposium. CabanasTavira, Portugal, May 19-23. 